\title{
Chemical Characterization of an Envelope A Sample from Hanford
} Tank 241-AN-103

by

M. S. Hay

Westinghouse Savannah River Company

Savannah River Site

Aiken, South Carolina 29808

M. G. Bronikowski

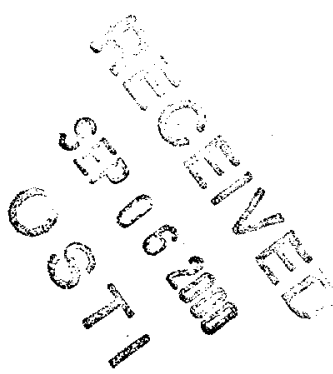

N. M. Hassan

DOE Contract No. DE-AC09-96SR18500

This paper was prepared in connection with work done under the above contract number with the U.S.

Department of Energy. By acceptance of this paper, the publisher and/or recipient acknowledges the U. S.

Government's right to retain a nonexclusive, royalty-free license in and to any copyright covering this paper, along with the right to reproduce and to authorize others to reproduce all or part of the copyrighted paper. 


\section{DISCLAIMER}

Portions of this document may be illegible in electronic image products. Images are produced from the best available original document. 


\title{
Chemical Characterization of an Envelope A Sample from Hanford Tank 241-AN-103
}

July 31,2000

\author{
M. S. Hay \\ M. G. Bronikowski \\ N. M. Hassan
}

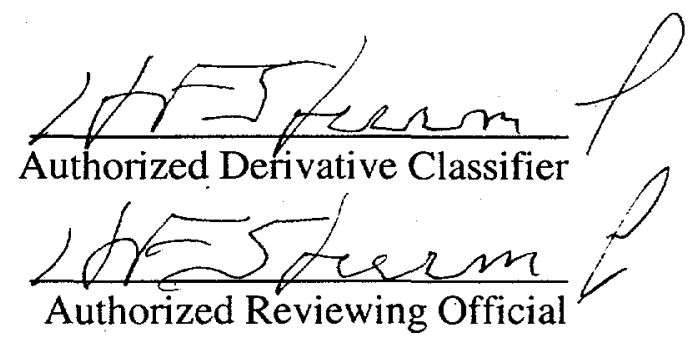

\section{DISCLAIMER}

This report was prepared as an account of work sponsored by an agency of the United States Government. Neither the United States Government nor any agency thereof, nor any of their employees, makes any warranty, express or implied, or assumes any legal liability or responsibility for the accuracy, completeness, or usefulness of any information, apparatus, product or process disclosed, or represents that its use would not infringe privately owned rights. Reference herein to any specific commercial product, process or service by trade name, trademark, manufacturer, or otherwise does not necessarily constitute or imply its endorsement, recommendation, or favoring by the United States Government or any agency thereof. The views and opinions of authors expressed herein do not necessarily state or reflect those of the United States Government or any agency thereof.

This report has been reproduced directly from the best available copy.

Available for sale to the public, in paper, from: U.S. Department of Commerce, National Technical Information Service, 5285 Port Royal Road, Springfield, VA 22161, phone: (800) 553-6847

fax: (703) 605-6900

email: orders@ntis.fedworld.gov

online ordering: http://www.ntis.gov/ordering.htm

Available electronically at http://www.doe.gov/bridge

Available for a processing fee to U.S. Department of Energy and its contractors, in paper, from: U.S. Department of Energy, Office of Scientific and Technical Information, P.O. Box 62, Oak Ridge, TN 37831-0062, phone: (865) 576-8401

fax: (865) 576-5728

email: reports@adonis.osti.gov 


\section{SUMMARY}

A whole tank composite sample from Hanford waste tank 241-AN-103 was received at the Savannah River Technology Center (SRTC) and chemically characterized. Prior to characterization the sample was diluted to $\sim 5 \mathrm{M}$ sodium concentration. The filtered supernatant liquid, the total dried solids of the diluted sample, and the washed insoluble solids obtained from filtration of the diluted sample were analyzed.

A mass balance calculation of the three fractions of the sample analyzed indicate the analytical results appear relatively self-consistent for major components of the sample. However, some inconsistency was observed between results where more than one method of determination was employed and for species present in low concentrations. A direct comparison to previous analyses of material from tank 241-AN-103 was not possible due to unavailability of data for diluted samples of tank 241-AN-103 whole tank composites. However, the analytical data for other types of samples from 241-AN-103 were mathematically diluted and compare reasonably with the current results. Although the segments of the core samples used to prepare the sample received at SRTC were combined in an attempt to produce a whole tank composite, determination of how well the results of the current analysis represent the actual composition of the Hanford waste tank 241-AN-103 remains problematic due to the small sample size and the large size of the non-homogenized waste tank.

\section{INTRODUCTION}

The BNFL River Protection Project contracted SRTC to provide pretreatment development and testing services to support the BNFL mission to treat Hanford tank waste. As part of the program, SRTC received radioactive Hanford tank waste samples to allow testing of the pretreatment processes with actual waste samples. The first step in this program entails detailed characterization of the radioactive waste samples. The characterization data provides a basis for rational development of pretreatment processes, determination of reagent requirements, and development of physical design parameters for the pretreatment plant.

The characterization portion of the STRC program was conducted under an approved task and quality assurance plan. ${ }^{1,2,3}$ The results and the associated uncertainties presented provide a description of the sample received at SRTC. The highly radioactive nature of the samples adds complexity to the analysis. Sub-sampling, large dilutions, and remote handling potentially add error to the analytical accuracy. Replicate sample analysis and submission of standards allow some definition of the magnitude of this error. However, the error associated with obtaining small samples from large non-homogenized waste tanks will be significant. Recent experience at SRS indicates a combined sampling and analytical error on the order of $15-20 \%$ associated with obtaining small samples from a well mixed waste tank. ${ }^{4}$ 
The data presented in this report documents the chemical characterization of a $1.2 \mathrm{~L}$ sample of Hanford waste tank 241-AN-103.

\section{EXPERIMENTAL}

\section{Sample History}

A total of 12 samples of 241-AN-103 were received at SRTC on 9-28-98. The sample jar labels from the 12 samples received at SRTC are listed in Table 1. Each jar is a composite formed by combining portions of segments from extrusion samples. ${ }^{5}$ The composites in each jar provide an average tank composition of 241-AN-103. The portions of each segment used to form the composites (P1 - P13) are listed in Tables 2 and 3.

After loading the samples into the Shielded Cells facility, the 12 samples were composited. The total volume of the composited samples was $\sim 1200 \mathrm{~mL}$. After sitting for several days, a thick layer of white solids formed on the bottom of the bottle. The volume of the settled solids was approximately half the volume of the sample.

The sample was thoroughly mixed by vigorously shaking the bottle and then split with one half stored as an archive for future work. The other half of the sample $(500 \mathrm{~mL})$ was diluted with $1025 \mathrm{~mL}$ of $0.01 \mathrm{M} \mathrm{NaOH}$ to a sodium concentration of $\sim 5 \mathrm{M}$. The sample was filtered through a $0.45 \mu$ nylon disposable filter to remove the small amount of insoluble solids present. Samples of the total dried solids of the diluted sample, the filtered supernatant liquid from the diluted material, and dried insoluble solids remaining after dilution were prepared for analysis and fully characterized. Weight percent solids and density measurements were made on the as-received composite sample, the sample after dilution to $\sim 5 \mathrm{M}$ sodium, and the filtered supernatant liquid from the diluted material. Due to the low solids content of the diluted sample a direct measurement of the weight percent insoluble solids was necessary. The filtered material was sent on for use in ion exchange studies.

The decision was made to process the other half $(450 \mathrm{~mL})$ of the as-received 241-AN-103 composite sample. After diluting to $\sim 5 \mathrm{M}$ sodium by adding $900 \mathrm{~mL}$ of $0.01 \mathrm{M} \mathrm{NaOH}$ and filtering to remove insoluble solids, the two halves of diluted 241-AN-103 were combined prior to ion exchange studies. A sample of the combined filtered supernatant liquid was also fully characterized.

\section{Sample Preparation}

A 12-fold dilution with deionized, distilled water was generally necessary to lower the radiation levels on filtered supernatant samples before submittal for analysis. Standards were not submitted with the supernatant samples, however, the Analytical Development Section periodically measures standards and blanks to check the calibration and background of the instruments. The total dried solids for the sample were obtained by thoroughly mixing the sample and any insoluble solids present by vigorously shaking the bottle, removing an aliquot of the sample, and drying the aliquot at $100{ }^{\circ} \mathrm{C}$ to constant weight to remove free water. The dried insoluble solids were obtained by filtering a 
portion of the sample through a $0.45 \mu$ filter and washing the solids obtained with a small amount of $0.01 \mathrm{M} \mathrm{NaOH}$ to remove interstitial supernatant liquid. The washed insoluble solids were then dried at $100{ }^{\circ} \mathrm{C}$ to constant weight to remove free water. Dissolution of samples of total dried solids and dried insoluble solids were performed in triplicate by contacting with aqua-regia or by fusion with sodium peroxide. The digested solids samples were diluted to $250 \mathrm{~mL}$ with deionized, distilled water before analysis. Quality control included dissolving a glass standard of known composition concurrently with the dried solids samples. The glass standard indicates potential problems with sample contamination or incomplete dissolution during the digestion procedure and systematic problems with the analytical procedures. Unless otherwise noted the glass standards showed a successful dissolution and accurate analyses.

\section{Analytical Methods}

Analytical Development Section (ADS) performed all analytical measurements with the exception of the weight percent solids and density measurements conducted in the Shielded Cells. ADS uses the following analytical methods for determination of specific species. Nitrate, nitrite, sulfate, oxalate, phosphate, formate, chloride, and fluoride were measured by ion chromatography (IC). Chloride and fluoride were also determined by the ion selective electrode (ISE) method. Aluminate, carbonate, and hydroxide were measured using a titration method employing $\mathrm{SrCl}_{2}$ to precipitate carbonate allowing the determination of all three species. Sodium, aluminum, and iron, as well as other metallic elements, were measured using inductively-coupled plasma-emission spectroscopy (ICPES). Potassium and mercury were measured using atomic adsorption spectroscopy (AA) with mercury determined using the cold-vapor technique (CV). Gamma emitting fission products were measured using gamma spectroscopy. Actinides were determined by inductively-coupled plasma mass spectrometry (ICP-MS) and alpha counting spectroscopy. $\mathrm{Sr}^{90}$ was determined from beta liquid scintillation counting. $\mathrm{Tc}^{99}$ was measured by ICP-MS and ICP-ES.

\section{Weight Percent Solids Analysis}

The weight percent of total solids in the samples were measured using a conventional drying oven at $100^{\circ} \mathrm{C}$ and stainless steel or polymethylpentene beakers. The weight percent of dissolved solids in a sample of the filtered supernate were measured in the same manner. The weight percent insoluble solids and soluble solids in the sample were calculated from the measurements of the weight percent total solids of the sample and the weight percent dissolved solids in the filtered supernate. Obtaining the weight percent solids analysis of samples in this manner avoids difficulties associated with reproducibly measuring the insoluble solids directly. For samples with less than $3 \mathrm{wt} \%$ insoluble solids a direct measurement is required. Equations 1 and 2 allow calculation of the weight percent of insoluble and soluble solids from the total solids and dissolved solids measurements. The weight percent of soluble solids gives the mass of the dissolved solids in the supernate expressed as a percentage of the mass of the sample. The weight percent of insoluble solids represents the mass of insoluble solids expressed as a percentage of the mass of the sample. A $15 \mathrm{wt} \% \mathrm{NaCl}$ standard solution was measured concurrently during the analysis of the samples. All measurements of the $15 \mathrm{wt} \% \mathrm{NaCl}$ standard solution were within $5 \%$ of the expected value. 
$w_{\mathrm{ds}}=$ weight fraction of dissolved solids

$w_{t s}=$ weight fraction of total solids

$w_{\text {is }}=$ weight fraction of insoluble solids

$\mathrm{w}_{\text {Ss }}=$ weight fraction of soluble solids

$w_{\text {is }}=\left(w_{t s}-w_{d s}\right) /\left(1-w_{d s}\right)$

$w_{s s}=w_{t s}-w_{\text {is }}$ (wt dissolved solids/ wt of supernate)

(wt total solids/ wt of sludge slurry)

(wt insoluble solids/ wt of sludge slurry)

(wt dissolved solids/ wt of sludge slurry)

\section{Density Measurements}

Density measurements were made on both the total sample and the filtered supernate using a pipette tip with the small end heat-sealed. After heat sealing, these pipette tips provide a reproducible volume of $8.25 \mathrm{~mL}$. The sample does not wet the pipette tips eliminating problems with entrained air bubbles when filling a narrow cylinder with thick slurries.

\section{RESULTS}

The 241-AN-103 sample received at SRTC consisted of a concentrated slurry containing a significant amount of precipitated salts as evidenced by the weight percent solids data shown in Table 4. Nearly all of the insoluble solids present in the as-received sample dissolved during dilution of the sample. The sodium, $\mathrm{Sr}^{90}$, and free hydroxide concentrations were monitored during the several steps required to dilute the as-received sample to the $\sim 5 \mathrm{M}$ sodium concentration needed for the ion exchange process (see Table 5). The sodium concentration gradually dropped with each successive dilution. The free hydroxide concentration dropped precipitously with the first dilution most likely due to the dissolution of aluminum salts. In contrast, the $\mathrm{Sr}^{90}$ concentration initially increased with the first dilution and then remained constant throughout the following dilution steps. This indicates significant dissolution of $\mathrm{Sr}^{90}$ from the insoluble solids present in the original as-received sample with each step of the dilution.

After diluting the first half of the 241-AN-103 sample to $~ 5 \mathrm{M}$ sodium concentration, the weight percent solids and density were measured again (see Table 4). Due to the low quantity of insoluble solids present after dilution a direct measurement of the weight percent insoluble solids was necessary. The single direct measurement of the insoluble solids content does not provide any accuracy statistics, however at these low solids concentrations the weight percent insoluble solids result of 0.1 probably should have error bands of $\pm 50 \%$. The diluted $241-\mathrm{AN}-103$ sample was then dead-end filtered to remove the small amount of insoluble solids.

The filtered supernatant liquid from the diluted sample was fully characterized. Table 6 lists the results for the analysis of non-radioactive species found in the filtered supernatant liquid. The sodium concentration at $5.25 \mathrm{M}$ was close to the targeted $5 \mathrm{M}$ 
required by the ion exchange process. Other metals with a significant concentration in the supernatant include aluminum, phosphorus, potassium, and chromium. The main anions in solution include nitrate, nitrite, and hydroxide. The cation concentrations versus anion concentrations show reasonable agreement (within 10\%) indicating a reasonably accurate and complete analysis. The cation/anion balance provides an indication of whether any significant species were missed or whether bias was present in the analytical methods for cations versus anions. The TIC result, assuming all of the inorganic carbon present as carbonate, equates to a carbonate concentration of $12600 \mathrm{mg} / \mathrm{L}$. Since the carbonate concentration was below the detection limits of the titration method no direct comparison can be made. However, the TIC result expressed as a carbonate concentration appears reasonable being less than the lower detection limit for carbonate by the titration method. The TOC (376 mg/L) is somewhat low with respect to the sum of the carbon concentrations calculated from the oxalate and formate anion concentrations $(457 \mathrm{mg} / \mathrm{L})$. Both aluminum and phosphorus metals as measured by ICP-ES do not agree well with the values obtained for the anionic equivalents $\left(\mathrm{AlO}_{2}{ }^{-}\right.$and $\left.\mathrm{PO}_{4}{ }^{3-}\right)$ measured by different methods. The aluminate and carbonate measured by titration after treatment with $\mathrm{SrCl}_{2}$ may be subject to potential error due to precipitation of other anions along with the carbonate or incomplete carbonate precipitation. The precipitation of aluminate and other anions along with the carbonate would lower the observed aluminate concentration and produce a high bias for the carbonate measurement assuming complete precipitation of carbonate. The method dilutes the sample by $\sim 40 \mathrm{X}$ which should reduce the potential of significant precipitation of other anions. However, the aluminum result by ICP-ES indicates that precipitation of aluminate along with the carbonate may have occurred. Precipitation of aluminate has not been observed with a standard containing. $0.5 \mathrm{M}$ aluminate, $0.5 \mathrm{M}$ carbonate, and $0.5 \mathrm{M}$ free hydroxide using the $\mathrm{SrCl}_{2}$ method. The precipitation of aluminate may also reduce the free hydroxide concentration.

Table 7 shows the results of the measurement of radioactive isotopes for the filtered supernatant liquid. The $\mathrm{Sr}^{90}$ value agrees well with concentration measured during the dilution of the 241-AN-103 sample (see Table 5). The $\mathrm{Cs}^{137}$ value listed in Table 7, obtained from gamma spectroscopy, agrees reasonably well with the value obtained for mass 137 from ICP-MS $(172 \mu \mathrm{Ci} / \mathrm{mL})$. Other gamma emitters were not detected due to the high $\mathrm{Cs}^{137}$ concentration. These comparisons between different analytical methods provide some level of assurance as to the quality of the data.

The total solids and insoluble solids of the diluted 241-AN-103 sample were fully characterized and the results shown in Tables 8 and 9 . The total solids includes the insoluble solids present in the sample as well as all of the dissolved salts. The insoluble solids were collected by filtration of the sample and washed with small portions of 0.01 $\mathrm{M} \mathrm{NaOH}$ to remove interstitial supernatant liquid. The higher number of species below detection limits and larger percent relative standard deviations for the analysis of the total solids with respect to the analysis of the insoluble solids results from the dilution of metals and radioisotopes by salts. For most of the elements listed in Table 8 the values represent the average of six replicate samples, three from the aqua-regia dissolution and three from the sodium peroxide fusion method. In some cases, only aqua-regia data or the data from the sodium peroxide fusion method were used. For example, only the sodium 
peroxide fusion data was used to calculate an average silicon value because silicon does not dissolve well with the aqua-regia method. Sodium data cannot be obtained from the sodium peroxide fusion method so only the aqua-regia data was used to calculate an average value. A standard glass of known composition dissolved along with the sample provides an indication of the quality of the dissolution and the presence of contamination introduced during the dissolution procedure.

The sodium concentration at $29 \mathrm{wt} \%$ dominates the total solids analysis. Other metals of significant concentration include aluminum, potassium, and silicon. In contrast, the insoluble solids contain high concentrations of aluminum, chromium, silicon, and calcium in addition to sodium.

The radionuclide data in Table 9 was obtained through counting techniques and ICP-MS. Gamma spectroscopy identified only $\mathrm{Cs}^{137}$ in the total solids but also detected $\mathrm{Co}^{60}$ in the insoluble solids. The $\mathrm{Tc}^{99}$ value for the insoluble solids, determined by ICP-MS (17.0 $\mu \mathrm{Ci} / \mathrm{g}$ ), agrees well with the value determined by ICP-ES in Table 8 when converted to similar units $(17.1 \mu \mathrm{Ci} / \mathrm{g})$. The significantly higher detection limits for Tc in the ICP-ES compared to ICP-MS do not allow the same comparison to be made for the total solids. The low actinide concentrations in both the total solids and the insoluble solids combined with the dilution necessary to analyze the samples account for the low precision of the replicates. The uranium isotopics show consistency between both sets of solids data with $\mathrm{U}^{238}$ accounting for $\sim 99 \%$ and $\mathrm{U}^{235}$ for $\sim 0.7 \%$ by weight of the total uranium. The plutonium isotopics between the total dried solids sample and the insoluble solids sample do not show good agreement indicating a problem with the data at least with respect to the two methods used for obtaining the data. $\mathrm{A} \mathrm{Pu}^{240}$ value obtained by subtracting the $\mathrm{Pu}^{239}$ value from the ICP-MS from the $\mathrm{Pu}^{239 / 240}$ value from alpha counting indicates poor agreement for the plutonium isotopics between the two samples. A ratio for $\mathrm{Pu}^{239}$ to $\mathrm{Pu}^{240}$ of 0.1 on a mass basis was found in the total solids sample while the insoluble solids show a ratio of $\sim 1.0$. Very low levels of $\mathrm{Cm}^{244}$ detected in the both the total solids and insoluble solids data appears to be the result of contamination introduced during sample preparation.

The second half of the 241-AN-103 sample was diluted to $\sim 5 \mathrm{M}$ sodium concentration and filtered through a $0.45 \mu$ disposable filter to provide additional material for ion exchange tests. The filtrate was combined with the filtrate from the first half of the 241AN-103 sample to form a diluted composite sample and re-analyzed. As shown in Table 10 the sodium, potassium, phosphorus, and chromium agree within 5\% of the analysis of the first half of the sample. The aluminum concentration in the diluted composite exceeds the concentration found in the first half of the sample by approximately $20 \%$. However, in contrast to the first half of the 241-AN-103 sample, the aluminum concentration in the diluted composite sample agrees well with the aluminate concentration as determined by titration method. The anion concentrations in the diluted composite show some variation with respect to the analysis of the first half of the 241-AN-103 sample. The nitrate, nitrite, and phosphate concentrations in the diluted composite are significantly lower while the aluminum, sulfate, oxalate, are significantly higher as compared to the analysis of the first half of the 241-AN-103 sample. The sum of the cation concentrations versus 
the sum of the anion concentrations agree within 5\%. The TIC and TOC in the diluted composite are each $-50 \%$ higher than in the first half sample. The TIC does not correlate well with the carbonate result being approximately $80 \%$ higher indicating incomplete precipitation of the carbonate by $\mathrm{SrCl}_{2}$. The TOC result agrees within $10 \%$ to the sum of the formate and oxalate as organic carbon sources. Some of the differences between the diluted composite and the first half sample may result from unequal amounts of insoluble solids in the two halves of the 241-AN-103 sample when originally split into two portions.

The data for the radionuclide concentrations in the diluted composite shown in Table 11 indicates fair agreement for the $\mathrm{Cs}^{137}, \mathrm{Sr}^{90}$, and uranium isotopes compared to the first half sample. However, the $\mathrm{Tc}^{99}$ concentration in the diluted composite exceeds the concentration in the first half sample by nearly $50 \%$.

Table 12 shows a check on the self-consistency of the data for the first half of 241-AN103 sample diluted $\sim 5 \mathrm{M}$ sodium. The table was generated by converting the filtered supernatant data to a total dried solids concentration basis followed by adding the converted filtered supernatant and insoluble solids data together based on the weight percent solids and density data. Theoretically, the sum of these two samples should be equal to the total dried solids analysis minus any material leached from the insoluble solids during washing with $0.01 \mathrm{M} \mathrm{NaOH}$. With the exception of sodium, potassium, aluminum and $\mathrm{Cs}^{137}$, all predominantly soluble species present in high concentrations, the data indicates relatively poor agreement between the filtered supernatant liquid, the total dried solids, and the insoluble solids samples. The poorest agreement exists for species predominantly found in the insoluble solids at low concentrations. Most of the values with high percent differences show combined filtered supernatant and insoluble solids values lower then the total solids values indicating the possibility that some material was washed from the insoluble solids or the value used for the weight percent insoluble solids in the calculation was low.

\section{COMPARISON TO PREVIOUS ANALYSES OF 241-AN-103 SAMPLES}

The samples from 241-AN-103 sent to SRTC were made up from two push core samples originally collected in 1996. The composition of the 1996 samples, Core 166 and Core 167 , were determined for the various segments of these cores. The composition of composites made by mixing various segments were also determined. These results have been reported in the tank characterization report for Tank $241-\mathrm{AN}-103 .{ }^{6}$ Neither the composite nor sectional samples were diluted to a $\sim 5 \mathrm{M}$ sodium concentration so a direct comparison to the experimental data in this report cannot be made. Two comparisons have been made; the first to values calculated from a weighted addition of segment compositions to simulate the makeup of the samples received at SRTC, and the second to a simple dilution of the core 166 composite values.

Table 13 shows the calculated chemical composition expected for the composites

received at SRTC for nine chemical species. The calculated composite concentrations 
were calculated utilizing the makeup of $\mathrm{P} 1$ as listed in Table 3 . The sum of all sample weights added to P1 was used to determine the weight percent each jar added to the P1 composite. The density and concentration, of each segment of the core were used to calculate a species concentration in $\mu \mathrm{g} / \mathrm{g}$ for each sample added to composite $\mathrm{P} 1$. For crust samples and few suspended solids samples without concentrations available, the composite solid values were used. The weight percent of each added jar sample was multiplied by its species concentration, thus giving the weight added by each jar to the composite sample P1. The density of each jar was also multiplied by its respective weight percent and summed to give a composite density of the resulting P1 sample. The sum of the jar weights was then divided by the composite density to determine the composite species concentration in $\mathrm{mg} / \mathrm{L}$ The first column of Table 13 contains this calculated composite composition converted to molar concentration. The referenced report contained sufficient data to calculate a composite concentration for only the nine species shown in the table.

The calculated composite values were then diluted mathematically. The dilution calculation used the ratio of the sodium concentration in the filtered supernatant liquid from the diluted first half of the 241-AN-103 received at SRTC (see Table 6) to the sodium concentration of the calculated composite (5.25/13.9). This calculation assumes that no solids precipitated during the dilution and that all solids present prior to dilution dissolve. The data from the calculated diluted composite and the filtered supernatant show reasonably good agreement given the assumptions required for the diluted composite calculation. The values for the diluted composite sample obtained by combining the first and second halves of the 241-AN-103 received at SRTC (see Table 10) shows even better agreement with the referenced data. The percent difference for aluminum drops from $29 \%$ to $3 \%$, the nitrate from $39 \%$ to $9 \%$, the nitrite from $19 \%$ to $7 \%$, and the chloride from $41 \%$ to $2 \%$. For all of the other species in the table the differences remain unchanged except for $\mathrm{Si}$ which increases from $35 \%$ to $70 \%$.

The average liquid composite and solid composite sample data from tank characterization report ${ }^{6}$ can also be compared to the data for the sample received at SRTC. The composite liquid sample was made by adding $40 \mathrm{~mL}$ of supernate from Core 166 segments $3,4,6$, $7,8,9,10,11$, and 12 . The solid composite sample, also called the non-convective layer salt slurry, was made by adding $10 \mathrm{~g}$ of each of Core 166 segments $1-19$. Only species with an actual measured value were included in the comparison.

The chemical composition of the liquid composite was mathematically diluted to a 5.25 $M$ sodium concentration using the ratio of the sodium concentration in the filtered supernatant liquid from the diluted first half of the $241-\mathrm{AN}-103$ received at SRTC (see Tables 6 and 7) to sodium concentration of the calculated composite (5.25/10.98). The comparison in Table 14 shows fair agreement for some species but large differences for others. Much of the difference in the compositions can be attributed to the fact that the sample received at SRTC was a whole tank composite containing $50 \%$ solids that dissolved during dilution. The liquid composite sample contained only supernatant liquid from select segments of Core 166. 
Table 15 shows a comparison of the solids composite to the total solids of the first half of the 241-AN-103 received at SRTC (see Tables 8 and 9). Only unit conversions were made on the solids composite data shown in the table. The two data sets show agreement of roughly $\pm 50 \%$.

\section{CONCLUSIONS}

The data obtained for the sample of 241-AN-103 received at SRTC appears relatively self-consistent for major components of the sample. Some inconsistency was observed between results where more than one method of determination was employed. Results for radionuclides present in low concentrations, namely the actinides, generally exhibit larger errors due to the difficulties in analyzing species present in low concentrations and the potential for introduction of small amounts of contamination during sample handling causing large uncertainties. The comparison to previous analyses of samples from 241AN-103 indicates general agreement with the current analytical results. However, since a direct comparison was not possible due to the differences in the type of samples that were analyzed, the validity or usefulness of the comparison should not be overstated.

Again, it should be stressed that the 241-AN-103 sample was made from combining portions of two core samples obtained from a large non-homogenized waste tank. Although the segments of the core samples were combined in an attempt to produce a whole tank composite, how the results of the current analysis relate to the actual composition of the Hanford waste tank 241-AN-103 is uncertain. 


\section{REFERENCES}

1. Hay, M. S. , "Task Technical and Quality Assurance Plan for Sample Characterization and Sludge Washing in Support of BNFL Part B", BNF-003-980013, Rev. 0, October 21, 1998.

2. Letter from M. E. Johnson (BNFL) to S. T. Wach (SRTC), "Analytical Requirements for Supernate and Sludge/Solids", BNFL Letter No. 000453, October 30,1998

3. Letter from M. E. Johnson (BNFL) to S. T. Wach (SRTC), "Physical Properties Measurement for Process Solutions Action Item 09/17/98-21", BNFL Letter No. 000115 , October 1,1998

4. Hay, M. S., Edwards, T. B., "Statistical Analysis of ESP Verification Test Samples", WSRC-RP-94-1224, November 4, 1994.

5. E-mail from M. E. Johnson to M. S. Hay, "Fwd: Additional Information on AN103", December 3, 1999.

6. Wilkins, N. E., Field, J. G., Welsh, T. L., "Tank Characterization for Double Shell Tank 241-AN-103", HNF-SD-WM-ER-702, Rev. 0, May 8, 1997. 
12

BNF-003-98-0248

Revision 0

APPROVALS

Authors

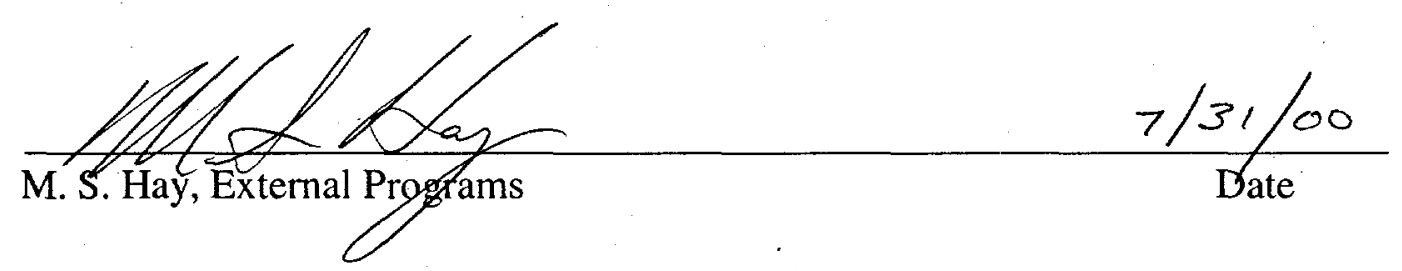

\begin{tabular}{ll} 
M Dronikoursti & $8 / 01 / 00$ \\
\hline M. G. Bronikowski, Actinide Laboratory Programs & Date
\end{tabular}

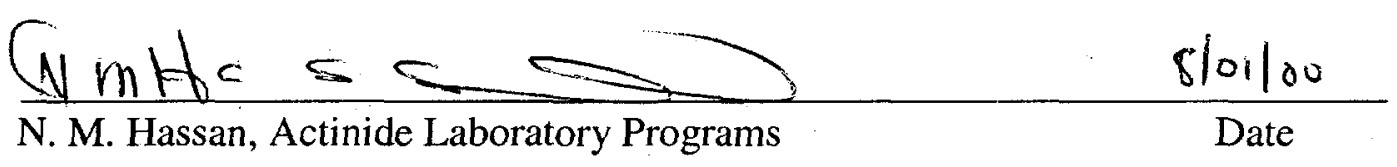

Design Check

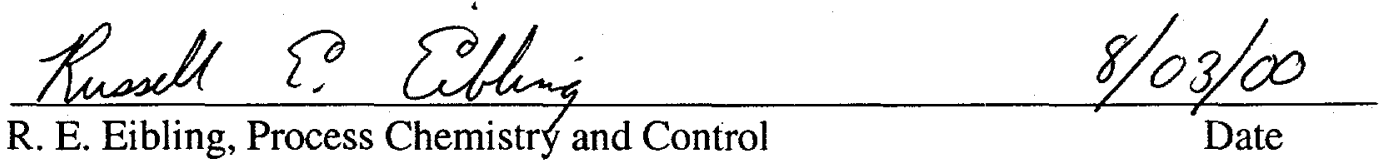

Management

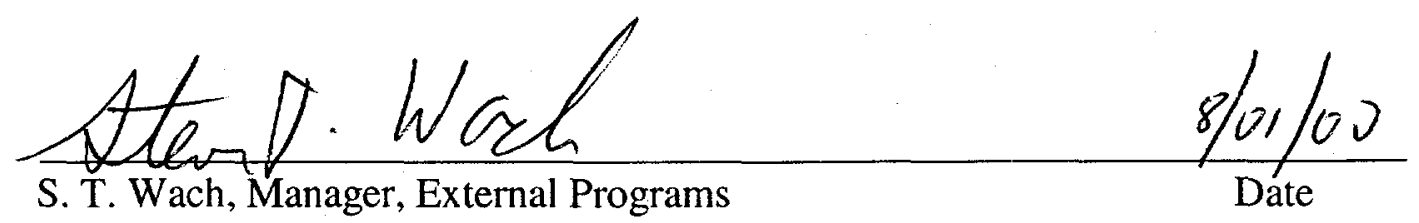


Table 1. Listing of Sample Labels from Bottles of AN-103 Sample Received at SRTC.

\begin{tabular}{|l|lc|}
\hline Jar No. & \multicolumn{1}{|c|}{ Jar Label } \\
\hline Jar 1 & AN-103 Composite P-1 & $222 S-98-000086$ \\
Jar 2 & AN-103 Composite P-2 & $222 S-98-000087$ \\
Jar 4 & AN-103 Composite P-3 & $222 S-98-000088$ \\
Jar 5 & AN-103 Composite P-4 & $222 S-98-000089$ \\
Jar 6 & AN-103 Composite P-5 & $222 S-98-000090$ \\
Jar 7 & AN-103 Composite P-6 & $222 S-98-000091$ \\
Jar 8 & AN-103 Composite P-7 & $222 S-98-000092$ \\
Jar 9 & AN-103 Composite P-9 & $222 S-98-000093$ \\
Jar 10 & AN-103 Composite P-10 & $222 S-98-000094$ \\
Jar 11 & AN-103 Composite P-11 & $222 S-98-000095$ \\
Jar 12 & AN-103 Composite P-12 & $222 S-98-000096$ \\
\hline
\end{tabular}


Table 2. Descriptions of Source Material for the Parent Jar No.

\begin{tabular}{|c|c|}
\hline Parent Jar No. & Description of source material \\
\hline 11396 & Slurried solids from core \#166 segment \#15U \\
\hline 11402 & Slurried solids from core \#166 segment \#15L \\
\hline 11413 & Drainable liquid from core \#166 segment \#3 \\
\hline 11485 & Suspended solids from core \#167 segment \#6 \\
\hline 11500 & Suspended solids from core \#167 segment \#5 \\
\hline 11502 & Slurried solids from core \#167 segment \#12L \\
\hline 11503 & Slurried solids from core \#167 segment \#12U \\
\hline 11504 & Slurried solids from core \#167 segment \#14U \\
\hline 11508 & Slurried solids from core \#166 segment \#15U \\
\hline 11509 & Slurried solids from core \#166 segment \#15L \\
\hline 11510 & Slurried solids from core \#166 segment \#17U \\
\hline 11511 & Slurried solids from core \#166 segment \#17L \\
\hline 11512 & Slurried solids from core \#167 segment \#14L \\
\hline 11515 & Slurried solids from core \#166 segment \#13U \\
\hline 11524 & Drainable liquid from core $\# 166$ segment $\# 3$ \\
\hline 11524 & Solids from core $\# 166$ segment $\# 3$ \\
\hline 11525 & Drainable liquid from core \#167 segment \#6 \\
\hline 11527 & Slurried solids from core \#167 segment \#15L \\
\hline 11528 & Drainable liquid from core \#166 segment \#10 \\
\hline 11531 & Slurried solids from core \#166 segment \#16U \\
\hline 11533 & Slurried solids from core \#166 segment \#16L \\
\hline 11534 & Drainable liquid from core $\# 167$ segment \#8 \\
\hline 11536 & Tank Crust Material \\
\hline 11537 & Drainable liquid from core \#166 segment \#6 \\
\hline 11539 & Drainable liquid from core \#166 segment \#11 \\
\hline 11546 & Drainable liquid from core $\# 167$ segment $\# 2$ \\
\hline 11553 & Slurried solids from core \#166 segment \#18L \\
\hline 11558 & Drainable liquid from core $\# 166$ segment $\# 12$ \\
\hline 11560 & Drainable liquid from core \#167 segment \#9 \\
\hline 11569 & Drainable liquid from core \#167 segment \#6 \\
\hline 11616 & Suspended solids from core $\# 166$ segment \#4 \\
\hline 11617 & Suspended solids from core $\# 166$ segment $\# 9$ \\
\hline 11618 & Suspended solids from core \#166 segment \#10 \\
\hline 11621 & Slurried solids from core \#167 segment \#17L \\
\hline 11622 & Slurried solids from core \#167 segment \#17U \\
\hline 11624 & Suspended solids from core \#166 segment \#11 \\
\hline 11634 & Slurried solids from core \#166 segment \#13L \\
\hline 11635 & Slurried solids from core \#166 segment \#18U \\
\hline 11636 & Slurried solids from core \#166 segment \#18L \\
\hline 11638 & Suspended solids from core \#167 segment \#7 \\
\hline 11775 & Tank Crust Material \\
\hline 11776 & Suspended solids from core \#166 segment \#12 \\
\hline 11777 & Slurried solids from core \#166 segment \#16U \\
\hline 11778 & Slurried solids from core \#166 segment \#16L \\
\hline 11779 & Suspended solids from core \#166 segment \#7 \\
\hline 11781 & Slurried solids from core \#166 segment \#19U \\
\hline 11782 & Slurried solids from core \#166 segment \#19L \\
\hline 11784 & Suspended solids from core \#167 segment \#9 \\
\hline 11785 & Tank Crust Material \\
\hline 11786 & Tank Crust Material \\
\hline 11790 & Slurried solids from core \#167 segment \#15U \\
\hline 11791 & Slurried solids from core \#167 segment \#15L \\
\hline
\end{tabular}


Table 3. Weights in Grams of each Parent Jar used to Form Composites Samples P1 - P13

\begin{tabular}{|c|c|c|c|c|c|c|c|c|c|}
\hline Parent Jar & P1 & P2 & $\mathbf{P 3}$ & P4 & P5 & P6 & P7 & P8 & P9 \\
\hline 11396 & 2.73 & 2.70 & 2.70 & 2.75 & 2.77 & 2.73 & 2.74 & 2.71 & 2.74 \\
\hline 11402 & 2.79 & 2.74 & 2.76 & 2.75 & 2.81 & 2.76 & 2.77 & 2.76 & 2.83 \\
\hline 11413 & 0.79 & 0.75 & 0.76 & 0.76 & 0.72 & 0.71 & 0.76 & 0.73 & 0.79 \\
\hline 11485 & 1.17 & 1.24 & 1.21 & 1.19 & 1.17 & 0.45 & 0.29 & 1.18 & 1.18 \\
\hline 11500 & 1.54 & 1.69 & 1.62 & 1.63 & 1.67 & 2.09 & 1.55 & 1.57 & 1.54 \\
\hline 11502 & 3.56 & 3.57 & 3.58 & 3.69 & 3.69 & 3.64 & 3.59 & 3.63 & 3.64 \\
\hline 11503 & 3.50 & 3.52 & 3.51 & 3.51 & 3.50 & 3.53 & 3.54 & 3.51 & 3.55 \\
\hline 11504 & 3.58 & 3.51 & 3.54 & 3.49 & 3.53 & 3.54 & 3.53 & 3.48 & 3.55 \\
\hline 11508 & 2.93 & 2.97 & 3.07 & 3.02 & 2.88 & 2.99 & 2.95 & 3.05 & 2.97 \\
\hline 11509 & 3.44 & 3.41 & 3.37 & 3.43 & 3.38 & 3.39 & 3.44 & 3.35 & 3.40 \\
\hline 11510 & 2.60 & 2.63 & 2.63 & 2.63 & 2.62 & 2.66 & 2.65 & 2.63 & 2.61 \\
\hline 11511 & 2.98 & 3.00 & 2.99 & 2.99 & 3.05 & 2.99 & 3.01 & 2.99 & 3.04 \\
\hline 11512 & 4.05 & 4.03 & 3.98 & 4.01 & 4.00 & 4.07 & 4.08 & 4.02 & 3.97 \\
\hline 11515 & 3.17 & 3.14 & 3.21 & 3.13 & 3.16 & 3.21 & 3.16 & 3.14 & 3.17 \\
\hline 11524 & 7.34 & 7.34 & 7.34 & 7.32 & 7.38 & 7.34 & 7.32 & 7.34 & 7.36 \\
\hline 11524 & 1.37 & 1.39 & 1.36 & 1.58 & 1.40 & 1.38 & 1.61 & 1.46 & 1.40 \\
\hline 11525 & 9.47 & 9.53 & 9.47 & 9.48 & 9.55 & 9.47 & 9.48 & 9.47 & 9.46 \\
\hline 11527 & 1.48 & 1.39 & 1.40 & 1.36 & 1.40 & 1.39 & 1.42 & 1.35 & 1.46 \\
\hline 11528 & 7.43 & 7.43 & 7.45 & 7.41 & 7.41 & 7.42 & 7.46 & 7.45 & 7.43 \\
\hline 11531 & 2.11 & 2.03 & 2.00 & 2.14 & 2.14 & 2.09 & 2.06 & 2.01 & 2.00 \\
\hline 11533 & 2.55 & 2.51 & 2.61 & 2.45 & 2.51 & 2.51 & 2.60 & 2.48 & 2.49 \\
\hline 11534 & 7.53 & 7.56 & 7.55 & 7.51 & 7.55 & 7.59 & 7.52 & 7.56 & 7.55 \\
\hline 11536 & 1.40 & 1.42 & 1.43 & 1.43 & 1.42 & 1.44 & 1.40 & 1.40 & 1.42 \\
\hline 11537 & 7.62 & 7.45 & 7.44 & 7.63 & 7.43 & 7.44 & 7.41 & 7.48 & 7.49 \\
\hline 11539 & 7.24 & 7.23 & 7.31 & 7.27 & 6.26 & 7.27 & 7.28 & 7.23 & 7.21 \\
\hline 11546 & 6.28 & 6.79 & 6.19 & 6.03 & 6.06 & 6.06 & 6.07 & 6.11 & 6.05 \\
\hline 11553 & 1.98 & 1.98 & 1.97 & 1.96 & 1.97 & 1.97 & 1.96 & 1.98 & 1.99 \\
\hline 11558 & 6.91 & 6.88 & 7.02 & 6.90 & 6.89 & 6.89 & 6.92 & 6.87 & 6.93 \\
\hline 11560 & 9.72 & 9.78 & 9.74 & 9.73 & 9.74 & 9.72 & 9.76 & 9.78 & 9.77 \\
\hline 11569 & 9.04 & 9.03 & 9.11 & 9.02 & 9.03 & 9.01 & 9.04 & 9.04 & 9.01 \\
\hline 11616 & 1.22 & 1.24 & 1.21 & 1.22 & 1.27 & 1.34 & 1.24 & 1.21 & 1.48 \\
\hline 11617 & 1.06 & 1.03 & 1.02 & 1.09 & 1.05 & 1.11 & 1.13 & 1.10 & 1.03 \\
\hline 11618 & 1.09 & 1.05 & 1.06 & 1.02 & 1.12 & 1.04 & 1.09 & 1.08 & 1.12 \\
\hline 11621 & 3.08 & 3.15 & 3.06 & 3.09 & 3.08 & 3.06 & 3.10 & 3.06 & 3.09 \\
\hline 11622 & 3.90 & 3.89 & 3.88 & 3.87 & 3.88 & 3.92 & 3.90 & 3.88 & 3.87 \\
\hline 11624 & 0.63 & 0.65 & 0.61 & 0.58 & 0.64 & 0.58 & 0.68 & 0.66 & 0.62 \\
\hline 11634 & 2.92 & 2.88 & 2.86 & 2.88 & 2.91 & 2.91 & 2.92 & 2.90 & 2.86 \\
\hline 11635 & 3.48 & 3.51 & 3.50 & 3.46 & 3.46 & 3.48 & 3.49 & 3.53 & 3.48 \\
\hline 11636 & 3.20 & 3.13 & 3.12 & 3.12 & 3.14 & 3.15 & 3.12 & 3.11 & 3.13 \\
\hline 11638 & 0.94 & 0.93 & 1.10 & 1.13 & 1.00 & 0.94 & 0.95 & 0.97 & 0.99 \\
\hline 11775 & 0.75 & 0.75 & 0.71 & 0.76 & 0.72 & 0.75 & 0.73 & 0.78 & 0.71 \\
\hline 11776 & 0.55 & 0.47 & 0.51 & 0.51 & 0.52 & 0.48 & 0.62 & 0.53 & 0.53 \\
\hline 11777 & 3.47 & 3.48 & 3.46 & 3.40 & 3.51 & 3.46 & 3.38 & 3.51 & 3.46 \\
\hline 11778 & 3.25 & 3.15 & 3.33 & 3.28 & 3.23 & 3.25 & 3.27 & 3.26 & 3.27 \\
\hline 11779 & 0.72 & 0.77 & 0.85 & 0.74 & 0.76 & 0.72 & 0.75 & 0.73 & 0.78 \\
\hline 11781 & 2.97 & 2.96 & 2.97 & 2.95 & 2.99 & 2.98 & 2.97 & 2.98 & 2.98 \\
\hline 11782 & 2.44 & 2.42 & 2.44 & 2.42 & 2.46 & 2.44 & 2.44 & 2.52 & 2.43 \\
\hline 11784 & 1.60 & 1.33 & 1.39 & 1.35 & 1.30 & 1.31 & 1.32 & 1.34 & 1.36 \\
\hline 11785 & 2.81 & 2.78 & 2.82 & 2.80 & 2.80 & 2.80 & 2.81 & 2.79 & 2.84 \\
\hline 11786 & 3.29 & 3.27 & 3.31 & 3.28 & 3.31 & 3.35 & 3.29 & 3.34 & 3.27 \\
\hline 11790 & 4.16 & 4.19 & 4.16 & 4.19 & 4.15 & 4.20 & 4.18 & 4.21 & 4.20 \\
\hline 11791 & 3.93 & 3.98 & 3.97 & 3.92 & 3.94 & 3.91 & 3.94 & 3.96 & 3.91 \\
\hline
\end{tabular}


Table 3. Weights in Grams of each Parent Jar used to Form Composites Samples P1 - P13 (Continued).

\begin{tabular}{|l|l|l|l|l|}
\hline Parent Jar & P10 & P11 & P12 & P13 \\
\hline 11396 & 2.76 & 2.79 & 2.76 & 2.82 \\
\hline 11402 & 2.78 & 2.80 & 2.76 & 2.77 \\
\hline 11413 & 0.73 & 0.73 & 0.72 & 0.73 \\
\hline 11485 & 1.16 & 1.18 & 1.20 & 1.26 \\
\hline 11500 & 1.61 & 1.54 & 1.55 & 1.60 \\
\hline 11502 & 3.57 & 3.59 & 3.63 & 3.63 \\
\hline 11503 & 3.50 & 3.47 & 3.53 & 3.55 \\
\hline 11504 & 3.48 & 3.57 & 3.58 & 3.70 \\
\hline 11508 & 2.98 & 3.04 & 2.99 & 2.99 \\
\hline 11509 & 3.35 & 3.45 & 3.42 & 3.38 \\
\hline 11510 & 2.66 & 2.65 & 2.69 & 2.64 \\
\hline 11511 & 3.00 & 3.03 & 3.01 & 3.01 \\
\hline 11512 & 4.02 & 4.12 & 4.13 & 4.07 \\
\hline 11515 & 3.20 & 3.18 & 3.18 & 3.17 \\
\hline 11524 & 7.35 & 7.39 & 7.37 & 7.34 \\
\hline 11524 & 1.43 & 1.56 & 1.33 & 1.58 \\
\hline 11525 & 9.49 & 9.50 & 9.44 & 9.45 \\
\hline 11527 & 1.43 & 1.36 & 1.39 & 1.39 \\
\hline 11528 & 7.43 & 7.48 & 7.45 & 7.46 \\
\hline 11531 & 2.07 & 2.08 & 2.04 & 2.14 \\
\hline 11533 & 2.64 & 2.47 & 2.42 & 2.43 \\
\hline 11534 & 7.52 & 7.54 & 7.58 & 7.59 \\
\hline 11536 & 1.41 & 1.43 & 1.42 & 1.41 \\
\hline 11537 & 7.42 & 7.41 & 7.46 & 7.46 \\
\hline 11539 & 7.21 & 7.27 & 7.23 & 7.24 \\
\hline 11546 & 6.07 & 6.07 & 6.03 & 6.04 \\
\hline 11553 & 1.95 & 1.98 & 1.97 & 1.98 \\
\hline 11558 & 6.88 & 6.87 & 6.88 & 6.87 \\
\hline 11560 & 9.76 & 9.74 & 9.74 & 9.76 \\
\hline 11569 & 9.07 & 9.03 & 9.11 & 9.03 \\
\hline 11616 & 1.20 & 1.23 & 1.23 & 1.18 \\
\hline 11617 & 1.05 & 1.06 & 1.08 & 1.11 \\
\hline 11618 & 1.11 & 1.05 & 1.05 & 1.02 \\
\hline 11621 & 3.08 & 3.08 & 3.06 & 3.09 \\
\hline 11622 & 3.90 & 3.88 & 3.87 & 3.87 \\
\hline 11624 & 0.59 & 0.62 & 0.60 & 0.65 \\
\hline 11634 & 2.96 & 2.92 & 2.88 & 2.87 \\
\hline 11635 & 3.43 & 3.53 & 3.46 & 3.49 \\
\hline 11636 & 3.13 & 3.13 & 3.13 & 3.14 \\
\hline 11638 & 1.09 & 0.92 & 0.96 & 0.92 \\
\hline 11775 & 0.75 & 0.81 & 0.75 & 0.75 \\
\hline 11776 & 0.60 & 0.46 & 0.57 & 0.51 \\
\hline 11777 & 3.49 & 3.53 & 3.49 & 3.44 \\
\hline 11778 & 3.27 & 3.21 & 3.24 & 3.24 \\
\hline 11779 & 0.76 & 0.75 & 0.75 & 0.73 \\
\hline 11781 & 2.96 & 2.97 & 2.97 & 2.96 \\
\hline 11782 & 2.41 & 2.44 & 2.43 & 2.43 \\
\hline 11784 & 1.34 & 1.35 & 1.31 & 1.35 \\
\hline 11785 & 2.80 & 2.80 & 2.79 & 2.81 \\
\hline 11786 & 3.31 & 3.27 & 3.31 & 3.31 \\
\hline 11790 & 4.23 & 4.23 & 4.19 & 4.20 \\
\hline 11791 & 3.97 & 3.92 & 3.93 & 3.95 \\
\hline & & & & \\
\hline
\end{tabular}


Table 4. Results of Weight Percent Solids and Density Measurements for 241-AN103 Sample As-Received and for the First Half of the Sample Diluted to $\sim 5 \mathrm{M}$ Sodium.

\begin{tabular}{|l|c|c|}
\hline & $\begin{array}{c}\text { As Received } \\
\text { AN-103 }\end{array}$ & $\begin{array}{c}\text { AN-103 } \\
\text { Diluted to 5.25 M Na }\end{array}$ \\
\hline wt \% Total Solids & $64.7(3)$ & $31.5(2)$ \\
wt \% Dissolved Solids & $53.1(3)$ & $30.4(1)$ \\
wt \% Insoluble Solids & $24.7^{*}$ & $0.1^{* *}$ \\
wt \% Soluble Solids & $40.0^{* * *}$ & $31.4^{* * *}$ \\
Density of Supernate, g/mL & 1.49 & 1.26 \\
Density of Slurry, g/mL & 1.58 & 1.28 \\
\hline
\end{tabular}

Percent relative standard deviation for triplicate measurements are shown in parentheses.

* Calculated from the wt $\%$ total solids and wt \% dissolved solids.

**Result of a single direct measurement.

$* * *$ Calculated from the difference between the wt $\%$ total solids and wt $\%$ insoluble solids.

Table 5. Behavior of Na, Sr, OH During Dilution of the First Half of the 241-AN-103 Sample to $\sim 5 \mathrm{M}$ Sodium with $0.01 \mathrm{M} \mathrm{NaOH}$

\begin{tabular}{|l|c|c|c|c|}
\hline & {$\left[\mathrm{Na}^{+}\right] \mathbf{M}$} & $\mathbf{S r}^{90} \boldsymbol{\mu} \mathbf{C i} / \mathbf{m L}$ & {$\left[\mathrm{OH}^{-}\right] \mathbf{M}$} & Total Volume \\
\hline As Received & 11.7 & 0.012 & 6.28 & $500 \mathrm{~mL}$ \\
1st Dilution & $\sim 8.5^{*}$ & 0.020 & 2.64 & $1025 \mathrm{~mL}$ \\
2nd Dilution & 7.5 & 0.022 & 2.40 & $1150 \mathrm{~mL}$ \\
3rd Dilution & 5.25 & 0.020 & 2.17 & $1525 \mathrm{~mL}$ \\
\hline
\end{tabular}

*Estimated from the sodium concentration of the resulting solution $(7.5 \mathrm{M})$ and the amount of $0.01 \mathrm{M} \mathrm{NaOH}$ added assuming simple dilution with no solids dissolution. 
Table 6. Concentration of Non-Radioactive Species in Filtered Supernatant of the First Half of the 241-AN-103 Sample Diluted to $\sim 5$ M Sodium.

\begin{tabular}{|c|c|c|c|}
\hline Element & $\begin{array}{c}\text { Average } \\
\text { Concentration } \\
\mathrm{mg} / \mathrm{L} \\
\end{array}$ & $\begin{array}{c}\text { Average } \\
\text { Concentration } \\
\mathbf{M} \\
\end{array}$ & $\begin{array}{c}\% \text { Relative Standard } \\
\text { Deviation }\end{array}$ \\
\hline $\mathrm{Ag}$ & $4.38 \mathrm{E}-01$ & $4.06 \mathrm{E}-06$ & 32 \\
\hline Al & $1.88 \mathrm{E}+04$ & $6.98 \mathrm{E}-01$ & 0.7 \\
\hline$B$ & $1.30 \mathrm{E}+01$ & $1.20 \mathrm{E}-03$ & 3.1 \\
\hline $\mathrm{Ba}$ & $<2.55 \mathrm{E}-01$ & $<1.85 \mathrm{E}-06$ & \\
\hline $\mathrm{Ca}$ & $<1.29 \mathrm{E}+00$ & $<3.21 \mathrm{E}-05$ & \\
\hline $\mathrm{Cd}$ & $5.73 \mathrm{E}-01$ & $5.09 \mathrm{E}-06$ & 5.5 \\
\hline $\mathrm{Co}$ & 5.31E-01 & $9.01 \mathrm{E}-06$ & 18 \\
\hline $\mathrm{Cr}$ & $7.33 \mathrm{E}+01$ & $1.41 \mathrm{E}-03$ & 0.4 \\
\hline $\mathrm{Cu}$ & $7.60 \mathrm{E}-01$ & $1.20 \mathrm{E}-05$ & 15 \\
\hline $\mathrm{Fe}$ & $<5.30 \mathrm{E}-01$ & $<9.50 \mathrm{E}-06$ & \\
\hline $\mathrm{Hg}$ & $<1.27 \mathrm{E}-01$ & $<6.35 \mathrm{E}-07$ & \\
\hline $\mathrm{K}$ & $4.74 E+03$ & $1.21 \mathrm{E}-01$ & 2.2 \\
\hline $\mathrm{La}$ & $<1.36 \mathrm{E}+00$ & $<9.81 \mathrm{E}-06$ & \\
\hline $\mathrm{Li}$ & $1.51 \mathrm{E}+00$ & $2.18 \mathrm{E}-04$ & 7.5 \\
\hline $\mathrm{Mg}$ & $<1.06 \mathrm{E}+00$ & $<4.35 \mathrm{E}-05$ & \\
\hline Mn & $1.57 \mathrm{E}-01$ & $2.86 \mathrm{E}-06$ & 9.7 \\
\hline Mo & $3.41 \mathrm{E}+01$ & $3.56 \mathrm{E}-04$ & 1.2 \\
\hline $\mathrm{Na}$ & $1.21 \mathrm{E}+05$ & $5.25 E+00$ & 1.0 \\
\hline $\mathrm{Ni}$ & 7.67E-01 & $1.31 \mathrm{E}-05$ & 22 \\
\hline$P$ & $3.01 E+02$ & $9.71 \mathrm{E}-03$ & 0.4 \\
\hline $\mathrm{Pb}$ & $3.55 \mathrm{E}+01$ & $1.71 \mathrm{E}-04$ & 2.9 \\
\hline $\mathrm{Si}$ & $1.26 \mathrm{E}+02$ & $4.48 \mathrm{E}-03$ & 1.2 \\
\hline Sn & $2.62 \mathrm{E}+01$ & $2.20 \mathrm{E}-04$ & 1.3 \\
\hline $\mathrm{Sr}$ & $<2.04 \mathrm{E}-01$ & $<2.33 \mathrm{E}-06$ & \\
\hline $\mathrm{Ti}$ & $<3.06 \mathrm{E}-01$ & $<6.38 \mathrm{E}-06$ & \\
\hline V & $4.51 \mathrm{E}-01$ & 8.84E-06 & 31 \\
\hline $\mathrm{Zn}$ & $<1.30 \mathrm{E}+00$ & $<1.99 \mathrm{E}-05$ & \\
\hline $\mathrm{Zr}$ & $1.15 E+00$ & $1.27 \mathrm{E}-05$ & 16 \\
\hline
\end{tabular}

Percent relative standard deviations are for analysis of three replicate samples. 
Table 6. Concentration of Non-Radioactive Species in Filtered Supernatant of the First Half of the 241-AN-103 Sample Diluted to $\sim 5$ M Sodium. (Continued)

\begin{tabular}{|l|c|c|c|}
\hline Analyte & $\begin{array}{c}\text { Average } \\
\text { Concentration } \\
\mathbf{m g} / \mathrm{L}\end{array}$ & $\begin{array}{c}\text { Average } \\
\text { Concentration } \\
\mathbf{M}\end{array}$ & $\begin{array}{c}\text { \% } \\
\text { Relative Standard } \\
\text { Deviation }\end{array}$ \\
\hline$\left[\mathrm{NO}_{3}{ }^{-}\right]$ & $9.74 \mathrm{E}+04$ & $1.57 \mathrm{E}+00$ & 1.4 \\
{$\left[\mathrm{NO}_{2}{ }^{-}\right]$} & $4.77 \mathrm{E}+04$ & $1.04 \mathrm{E}+00$ & 2.5 \\
{$\left[\mathrm{PO}_{4}{ }^{3-}\right]$} & $6.54 \mathrm{E}+02$ & $6.88 \mathrm{E}-03$ & 0.8 \\
{$\left[\mathrm{SO}_{4}{ }^{2-}\right]$} & $7.43 \mathrm{E}+02$ & $7.73 \mathrm{E}-03$ & 0.8 \\
{$\left[\mathrm{C}_{2} \mathrm{O}_{4}{ }^{2-}\right]$} & $5.18 \mathrm{E}+02$ & $5.88 \mathrm{E}-03$ & 4.9 \\
{$\left[\mathrm{Cl}^{-}\right]$} & $2.18 \mathrm{E}+03$ & $6.15 \mathrm{E}-02$ & 8.7 \\
{$\left[\mathrm{~F}^{-2}\right.$} & $1.61 \mathrm{E}+02$ & $8.49 \mathrm{E}-03$ & 4.9 \\
{$\left[\mathrm{CHO}_{2}{ }^{-}\right]$} & $1.18 \mathrm{E}+03$ & $2.63 \mathrm{E}-02$ & 1.2 \\
{$\left[\mathrm{OH}^{-}\right]$free } & $4.27 \mathrm{E}+04$ & $2.17 \mathrm{E}+00$ & 3.9 \\
{$\left[\mathrm{CO}_{3}{ }^{2-}\right]$} & $<1.53 \mathrm{E}+04$ & $<2.55 \mathrm{E}-01$ & 13 \\
{$\left[\mathrm{AlO}_{2}{ }^{-}\right]$} & $2.36 \mathrm{E}+04$ & $3.99 \mathrm{E}-01$ & 14 \\
$\mathrm{TIC}^{2 \mathrm{C}}$ & $2.52 \mathrm{E}+03$ & $*$ & 38 \\
$\mathrm{TOC}^{2}$ & $3.76 \mathrm{E}+02$ & $*$ & \\
\hline
\end{tabular}

Percent relative standard deviations are for analysis of three replicate samples.

*Cannot calculate molar concentrations without knowing the specific compounds represented by the analytical result. 
Table 7. Concentration of Radioactive Species in Filtered Supernatant of the First Half of the 241-AN-103 Sample Diluted to $\sim 5$ M Sodium.

\begin{tabular}{|l|c|c|c|}
\hline Analyte & $\begin{array}{c}\text { Average } \\
\text { Concentration } \\
\mathbf{m g} / \mathrm{L}\end{array}$ & $\begin{array}{c}\text { Average } \\
\text { Concentration } \\
\mu \mathrm{Ci} / \mathbf{m L}\end{array}$ & $\begin{array}{c}\text { \% } \\
\text { Relative Standard } \\
\text { Deviation }\end{array}$ \\
\hline $\mathrm{Sr}^{\mathbf{9}}$ & $1.45 \mathrm{E}-04$ & $1.99 \mathrm{E}-02$ & 38 \\
$\mathrm{Tc}^{99} *$ & $1.94 \mathrm{E}+00$ & $3.30 \mathrm{E}-02$ & 32 \\
$\mathrm{Cs}^{133} *$ & $3.61 \mathrm{E}+00$ & Stable & 5.6 \\
$\mathrm{Cs}^{135} *$ & $1.48 \mathrm{E}+00$ & $1.70 \mathrm{E}-03$ & 4.2 \\
$\mathrm{Cs}^{137} *$ & $1.98 \mathrm{E}+00$ & $1.72 \mathrm{E}+02$ & 3.2 \\
$\mathrm{Cs}^{137}$ & $2.23 \mathrm{E}+00$ & $1.94 \mathrm{E}+02$ & 0.5 \\
$\mathrm{U}^{235} *$ & $4.20 \mathrm{E}-02$ & $9.01 \mathrm{E}-08$ & 4.2 \\
$\mathrm{U}^{238} *$ & $5.52 \mathrm{E}+00$ & $1.85 \mathrm{E}-06$ & 0.3 \\
Total Alpha & $* *$ & $1.80 \mathrm{E}-03$ & 16 \\
\hline
\end{tabular}

Percent relative standard deviations are for analysis of three replicate samples.

*Determined by ICP-MS

**Cannot calculate $\mathrm{mg} / \mathrm{L}$ concentrations without knowing the specific isotopes represented by the analytical result. 
Table 8. Concentration of Non-Radioactive Species in Total Dried Solids and Insoluble Dried Solids of the First Half of the 241-AN-103 Sample after Dilution to $\sim 5.0$ M Sodium.

\begin{tabular}{|c|c|c|c|c|}
\hline \multirow[b]{2}{*}{ Element } & \multicolumn{2}{|c|}{ 241-AN-103 Total Solids } & \multicolumn{2}{|c|}{ 241-AN-103 Insoluble Solids } \\
\hline & $\begin{array}{c}\text { Average } \\
\text { Concentration } \\
\text { Wt\% } \\
\end{array}$ & $\begin{array}{l}\text { \% Relative } \\
\text { Standard } \\
\text { Deviation }\end{array}$ & $\begin{array}{c}\text { Average } \\
\text { Concentration } \\
\text { Wt } \% \\
\end{array}$ & $\begin{array}{l}\text { \% Relative } \\
\text { Standard } \\
\text { Deviation }\end{array}$ \\
\hline $\mathrm{Al}$ & $5.94 \mathrm{E}+00$ & 33 & $1.23 \mathrm{E}+01$ & 2.2 \\
\hline B & $<1.5 \mathrm{E}-02$ & & $3.79 \mathrm{E}-02$ & 15 \\
\hline $\mathrm{Ba}$ & $<8.2 \mathrm{E}-03$ & & $3.07 \mathrm{E}-02$ & 4.7 \\
\hline $\mathrm{Ca}$ & $9.89 \mathrm{E}-02$ & 26 & $1.07 \mathrm{E}+00$ & 7.7 \\
\hline $\mathrm{Cd}$ & $<3.1 \mathrm{E}-03$ & & $8.59 \mathrm{E}-02$ & 2.4 \\
\hline $\mathrm{Co}$ & $<6.1 \mathrm{E}-03$ & & $<1.5 \mathrm{E}-02$ & \\
\hline $\mathrm{Cr}$ & $6.61 \mathrm{E}-02$ & 35 & $6.02 E+00$ & 1.6 \\
\hline $\mathrm{Cu}$ & $<1.9 \mathrm{E}-02$ & & $5.07 \mathrm{E}-02$ & 34 \\
\hline $\mathrm{Fe}$ & 7.47E-02 & 42 & $9.86 \mathrm{E}-01$ & 3.7 \\
\hline $\mathrm{Hg}$ & $1.01 \mathrm{E}-03$ & 1.6 & $9.99 \mathrm{E}-04$ & 0.5 \\
\hline $\mathrm{K}$ & $1.05 \mathrm{E}+00$ & 0.5 & 3.15E-02 & 9.5 \\
\hline $\mathrm{La}$ & $<2.9 \mathrm{E}-02$ & & $<2.8 \mathrm{E}-02$ & \\
\hline $\mathrm{Li}$ & $<1.4 \mathrm{E}-02$ & & $6.44 \mathrm{E}-01$ & 2.2 \\
\hline $\mathrm{Mg}$ & $9.64 \mathrm{E}-03$ & 66 & 7.69E-02 & 8.1 \\
\hline $\mathrm{Mn}$ & $1.82 \mathrm{E}-02$ & 9.7 & $8.02 \mathrm{E}-02$ & 1.6 \\
\hline Mo & $9.85 \mathrm{E}-03$ & 39 & $<8.1 \mathrm{E}-03$ & \\
\hline $\mathrm{Na}$ & $2.93 \mathrm{E}+01$ & 1.9 & $1.36 \mathrm{E}+01$ & 0.8 \\
\hline $\mathrm{Ni}$ & $<1.7 \mathrm{E}-02$ & & $2.15 \mathrm{E}-01$ & 2.1 \\
\hline $\mathbf{P}$ & $7.40 \mathrm{E}-02$ & 13 & $<8.9 \mathrm{E}-02$ & \\
\hline $\mathrm{Pb}$ & $<6.4 \mathrm{E}-02$ & & $2.72 \mathrm{E}-01$ & 5.0 \\
\hline $\mathrm{Ru}$ & $<5.0 \mathrm{E}-03$ & & $<4.9 \mathrm{E}-02$ & \\
\hline $\mathrm{Si}$ & $1.44 \mathrm{E}-01$ & 21 & $4.86 \mathrm{E}+00$ & 1.8 \\
\hline Sn & $1.91 \mathrm{E}-02$ & 6.7 & $<1.7 \mathrm{E}-02$ & \\
\hline $\mathrm{Sr}$ & $<3.1 \mathrm{E}-03$ & & $4.88 \mathrm{E}-03$ & 10 \\
\hline Tc & $<1.8 \mathrm{E}-02$ & & $1.01 \mathrm{E}-01$ & 5.1 \\
\hline $\mathrm{Ti}$ & $<1.5 \mathrm{E}-02$ & & $<1.2 \mathrm{E}-02$ & \\
\hline $\mathrm{V}$ & $<1.6 \mathrm{E}-02$ & & $<1.6 \mathrm{E}-02$ & \\
\hline $\mathrm{Zn}$ & $7.55 \mathrm{E}-03$ & 24 & 2.05E-01 & 1.9 \\
\hline $\mathrm{Zr}$ & $<1.88 \mathrm{E}-02$ & & $5.09 \mathrm{E}-02$ & 22 \\
\hline
\end{tabular}

Percent relative standard deviations are for analysis of three to six replicate samples. 
Table 9. Concentration of Radioactive Species in Total Dried Solids and Insoluble Dried Solids of the First Half of the 241-AN-103 Sample after Dilution to $\sim 5.0 \mathrm{M}$ Sodium.

\begin{tabular}{|c|c|c|c|c|}
\hline \multirow[b]{2}{*}{ Isotope } & \multicolumn{2}{|c|}{ 241-AN-103 Total Solids } & \multicolumn{2}{|c|}{ 241-AN-103 Insoluble Solids } \\
\hline & $\begin{array}{c}\text { Average } \\
\text { Concentration } \\
\mu \mathrm{Ci} / \mathrm{g}\end{array}$ & $\begin{array}{l}\text { \% Relative } \\
\text { Standard } \\
\text { Deviation }\end{array}$ & $\begin{array}{c}\text { Average } \\
\text { Concentration } \\
\mu \mathrm{Ci} / \mathrm{g} \\
\end{array}$ & $\begin{array}{l}\text { \% Relative } \\
\text { Standard } \\
\text { Deviation }\end{array}$ \\
\hline $\mathrm{Co}^{60}$ & Not detected & & $3.49 \mathrm{E}-01$ & 9.9 \\
\hline $\mathrm{Sr}^{90}$ & $4.79 E+00$ & 35 & $3.14 \mathrm{E}+02$ & 17 \\
\hline $\mathrm{Tc}^{99} *$ & $2.86 \mathrm{E}-01$ & 32 & $1.70 \mathrm{E}+01$ & 4.6 \\
\hline $\mathrm{Cs}^{137}$ & $5.12 \mathrm{E}+02$ & 34 & $1.18 \mathrm{E}+03$ & 1.7 \\
\hline $\mathrm{U}^{233} *$ & Not detected & & $4.99 \mathrm{E}-02$ & 8.7 \\
\hline $\mathrm{U}^{235} *$ & $9.05 \mathrm{E}-07$ & 34 & $6.76 \mathrm{E}-05$ & 8.0 \\
\hline $\mathrm{U}^{238} *$ & $1.86 \mathrm{E}-05$ & 28 & $1.54 \mathrm{E}-03$ & 5.6 \\
\hline $\mathrm{Pu}^{238} / \mathrm{Am}^{241}$ & $1.52 \mathrm{E}+00$ & 38 & $3.27 \mathrm{E}+00$ & 16 \\
\hline $\mathrm{Pu}^{239 / 240}$ & $1.04 \mathrm{E}+00$ & 57 & $4.45 \mathrm{E}-01$ & 34 \\
\hline $\mathrm{Pu}^{239} *$ & $2.85 \mathrm{E}-02$ & 29 & $1.00 \mathrm{E}-01$ & 58 \\
\hline $\mathrm{Pu}^{240} * *$ & $1.02 \mathrm{E}+00$ & & $3.44 \mathrm{E}-01$ & \\
\hline $\mathrm{Np}^{237} *$ & Not detected & & $9.19 \mathrm{E}-04$ & 8.6 \\
\hline
\end{tabular}

Percent relative standard deviations are for analysis of three to six replicate samples.

*Determined by ICP-MS

**Calculated by subtracting the $\mathrm{Pu}^{239}$ value from the ICP-MS from the $\mathrm{Pu}^{239 / 240}$ value from alpha counting. 
Table 10. Concentration of Non-Radioactive Species in Filtered Supernatant of a Composite of the First and Second Halves of the 241-AN-103 Sample after each was Diluted to $\sim 5.0$ M Sodium.

\begin{tabular}{|c|c|c|c|}
\hline Element & $\begin{array}{c}\text { Average } \\
\text { Concentration } \\
\mathrm{mg} / \mathrm{L} \\
\end{array}$ & $\begin{array}{c}\text { Average } \\
\text { Concentration } \\
\mathbf{M} \\
\end{array}$ & $\begin{array}{c}\% \text { Relative Standard } \\
\text { Deviation }\end{array}$ \\
\hline $\mathrm{Al}$ & $2.25 E+04$ & 8.34E-01 & 3.9 . \\
\hline B & $1.35 \mathrm{E}+01$ & $1.25 \mathrm{E}-03$ & 4.3 \\
\hline $\mathrm{Ba}$ & $<2.97 \mathrm{E}-01$ & $<2.16 \mathrm{E}-06$ & \\
\hline $\mathrm{Ca}$ & $6.04 \mathrm{E}+00$ & $1.51 \mathrm{E}-04$ & 4.2 \\
\hline $\mathrm{Cd}$ & $5.78 \mathrm{E}-01$ & $5.14 \mathrm{E}-06$ & 28 \\
\hline $\mathrm{Co}$ & $<8.06 \mathrm{E}-01$ & $<1.37 \mathrm{E}-05$ & \\
\hline $\mathrm{Cr}$ & $7.46 \mathrm{E}+01$ & $1.44 \mathrm{E}-03$ & 4.2 \\
\hline $\mathrm{Cu}$ & $<8.91 \mathrm{E}-01$ & $<1.40 \mathrm{E}-05$ & \\
\hline $\mathrm{Fe}$ & $<6.04 \mathrm{E}-01$ & $<1.08 \mathrm{E}-05$ & \\
\hline $\mathrm{Hg}$ & $<1.49 \mathrm{E}-01$ & $<7.40 \mathrm{E}-07$ & \\
\hline K & $4.57 \mathrm{E}+03$ & $1.17 \mathrm{E}-01$ & 2.8 \\
\hline $\mathrm{La}$ & $<1.93 \mathrm{E}+00$ & $<1.39 \mathrm{E}-05$ & \\
\hline $\mathrm{Li}$ & $1.10 \mathrm{E}+00$ & $1.59 \mathrm{E}-04$ & 33 \\
\hline $\mathrm{Mg}$ & $<1.49 \mathrm{E}-01$ & $<6.11 \mathrm{E}-06$ & \\
\hline $\mathrm{Mn}$ & $<1.78 \mathrm{E}-01$ & $<3.24 \mathrm{E}-06$ & \\
\hline Mo & $3.73 E+01$ & 3.89E-04 & 4.9 \\
\hline $\mathrm{Na}$ & $1.15 E+05$ & $4.99 \mathrm{E}+00$ & 3.1 \\
\hline $\mathrm{Ni}$ & $<1.93 \mathrm{E}+00$ & $<3.29 \mathrm{E}-05$ & \\
\hline $\mathbf{P}$ & $3.07 \mathrm{E}+02$ & $9.90 \mathrm{E}-03$ & 3.4 \\
\hline $\mathrm{Pb}$ & $3.68 \mathrm{E}+01$ & $1.78 \mathrm{E}-04$ & 10 \\
\hline Ru & $<7.28 \mathrm{E}+00$ & $<7.20 \mathrm{E}-05$ & \\
\hline $\mathrm{Si}$ & $9.47 \mathrm{E}+01$ & $3.37 \mathrm{E}-03$ & 80 \\
\hline Sn & $6.52 E+01$ & $5.50 \mathrm{E}-04$ & 92 \\
\hline $\mathrm{Sr}$ & $<9.58 \mathrm{E}+00$ & $<1.09 \mathrm{E}-04$ & \\
\hline $\mathrm{Tc}$ & $<1.81 \mathrm{E}+00$ & $<1.83 \mathrm{E}-05$ & \\
\hline $\mathrm{Ti}$ & $<3.44 \mathrm{E}-01$ & $<7.19 \mathrm{E}-06$ & \\
\hline V & $<1.30 \mathrm{E}+00$ & $<2.56 \mathrm{E}-05$ & \\
\hline $\mathrm{Zn}$ & $<4.46 \mathrm{E}-01$ & $<6.8 \mathrm{IE}-06$ & \\
\hline $\mathrm{Zr}$ & $<8.29 \mathrm{E}-01$ & $<9.09 \mathrm{E}-06$ & \\
\hline
\end{tabular}

Percent relative standard deviations are for analysis of three replicate samples. 
Table 10. Concentration of Non-Radioactive Species in Filtered Supernatant of a Composite of the First and Second Halves of the 241-AN-103 Sample after each was Diluted to $\sim 5.0$ M Sodium (Continued)

\begin{tabular}{|c|c|c|c|}
\hline Analyte & $\begin{array}{c}\text { Average } \\
\text { Concentration } \\
\text { mg/L }\end{array}$ & $\begin{array}{c}\text { Average } \\
\text { Concentration } \\
\mathbf{M} \\
\end{array}$ & $\begin{array}{c}\% \text { Relative Standard } \\
\text { Deviation }\end{array}$ \\
\hline$\left[\mathrm{NO}_{3}{ }^{-}\right]$ & $6.19 \mathrm{E}+04$ & $9.98 \mathrm{E}-01$ & 8.8 \\
\hline$\left[\mathrm{NO}_{2}^{-}\right]$ & $3.98 \mathrm{E}+04$ & $8.66 \mathrm{E}-01$ & 3.7 \\
\hline$\left[\mathrm{PO}_{4}{ }^{3-}\right]$ & $5.59 \mathrm{E}+02$ & $5.89 \mathrm{E}-03$ & 17 \\
\hline$\left[\mathrm{SO}_{4}{ }^{2-}\right]$ & $8.66 \mathrm{E}+02$ & $9.02 \mathrm{E}-03$ & 12 \\
\hline$\left[\mathrm{C}_{2} \mathrm{O}_{4}{ }^{2-}\right]$ & $6.04 \mathrm{E}+02$ & $6.86 \mathrm{E}-03$ & 15 \\
\hline$\left[\mathrm{Cl}^{-}\right]$ & $3.00 \mathrm{E}+03$ & $8.46 \mathrm{E}-02$ & 12 \\
\hline$[F]$ & $9.40 \mathrm{E}+01$ & 4.95E-03 & 8.3 \\
\hline$\left[\mathrm{CHO}_{2}^{-}\right]$ & $1.25 \mathrm{E}+03$ & $2.77 \mathrm{E}-02$ & 11 \\
\hline$\left[\mathrm{OH}^{-}\right]$free & $3.18 \mathrm{E}+04$ & $1.87 \mathrm{E}+00$ & 1.4 \\
\hline$\left[\mathrm{CO}_{3}{ }^{2-}\right]$ & $1.01 E+04$ & $1.68 \mathrm{E}-01$ & 11 \\
\hline$\left[\mathrm{AlO}_{2}^{-}\right]$ & $4.81 E+04$ & $8.16 \mathrm{E}-01$ & 2.2 \\
\hline TIC & $3.68 \mathrm{E}+03$ & $*$ & 7.4 \\
\hline TOC & $5.68 \mathrm{E}+02$ & $*$ & 26 \\
\hline
\end{tabular}

Percent relative standard deviations are for analysis of three replicate samples.

*Cannot calculate molar concentrations without knowing the specific compounds represented by the analytical result. 
Table 11. Concentration of Radioactive Species in Filtered Supernatant of a Composite of the First and Second Halves of the 241-AN-103 Sample after each was Diluted to $\sim 5.0$ M Sodium.

\begin{tabular}{|l|c|c|c|}
\hline Analyte & $\begin{array}{c}\text { Average } \\
\text { Concentration } \\
\mathbf{m g} / \mathrm{L}\end{array}$ & $\begin{array}{c}\text { Average } \\
\text { Concentration } \\
\mu \mathrm{Ci} / \mathbf{m L}\end{array}$ & $\begin{array}{c}\text { \% Relative Standard } \\
\text { Deviation }\end{array}$ \\
\hline $\mathrm{Sr}^{90}$ & $1.13 \mathrm{E}-04$ & $1.55 \mathrm{E}-02$ & 2.5 \\
$\mathrm{Tc}^{99} *$ & $3.08 \mathrm{E}+00$ & $5.23 \mathrm{E}-02$ & 6.3 \\
$\mathrm{Cs}^{133} *$ & $4.31 \mathrm{E}+00$ & stable & 3.6 \\
$\mathrm{Cs}^{135} *$ & $1.33 \mathrm{E}+00$ & $1.53 \mathrm{E}-03$ & 3.8 \\
$\mathrm{Cs}^{137} *$ & $1.76 \mathrm{E}+00$ & $1.52 \mathrm{E}+02$ & 4.0 \\
$\mathrm{Cs}^{137}$ & $2.30 \mathrm{E}+00$ & $2.00 \mathrm{E}+02$ & 2.4 \\
$\mathrm{U}^{235} *$ & $3.10 \mathrm{E}-02$ & $6.75 \mathrm{E}-08$ & 3.9 \\
$\mathrm{U}^{238} *$ & $4.08 \mathrm{E}+00$ & $1.37 \mathrm{E}-06$ & 4.6 \\
$\mathrm{Pu}^{238}$ & $3.19 \mathrm{E}-05$ & $5.46 \mathrm{E}-04$ & 5.5 \\
$\mathrm{Pu}^{239 / 240}$ & $* *$ & $2.00 \mathrm{E}-04$ & 17 \\
$\mathrm{Am}^{241}$ & $3.67 \mathrm{E}-05$ & $1.25 \mathrm{E}-04$ & 22 \\
$\mathrm{Cm}^{244}$ & $4.43 \mathrm{E}-07$ & $3.58 \mathrm{E}-05$ & 46 \\
$\mathrm{Total} \mathrm{Alpha}^{238}$ & $* *$ & $9.07 \mathrm{E}-04$ & 3.8 \\
\hline
\end{tabular}

Percent relative standard deviations are for analysis of three replicate samples.

*Determined by ICP-MS

**Cannot calculate $\mathrm{mg} / \mathrm{L}$ concentrations without knowing the specific isotopes represented by the analytical result. 
Table 12. Comparison of the Concentrations in the Total Dried Solids Sample Versus the Sum of the Filtered Supernatant and Insoluble Dried Solids Samples of the First Half of the 241-AN-103 Sample Diluted to $\sim 5$ M Sodium.

\begin{tabular}{|c|c|c|c|c|}
\hline & Units & Total Dried Solids & $\begin{array}{c}\text { Filtrate and } \\
\text { Insoluble Solids }\end{array}$ & $\begin{array}{c}\text { Percent } \\
\text { Difference }\end{array}$ \\
\hline \multicolumn{5}{|l|}{ Counting } \\
\hline $\mathrm{Cs}^{137}$ & $\mathrm{uCi} / \mathrm{g}$ & $5.12 \mathrm{E}+02$ & $5.10 \mathrm{E}+02$ & $0.5 \%$ \\
\hline $\mathrm{Sr}^{90}$ & $\mathrm{uCi} / \mathrm{g}$ & $4.79 E+00$ & $1.05 \mathrm{E}+00$ & $78 \%$ \\
\hline \multicolumn{5}{|l|}{ ICP-ES } \\
\hline $\mathrm{Al}$ & $\mathrm{wt} \%$ & $5.94 \mathrm{E}+00$ & $4.96 \mathrm{E}+00$ & $16 \%$ \\
\hline $\mathrm{Ca}$ & wt\% & $9.89 \mathrm{E}-02$ & $3.73 \mathrm{E}-03$ & $96 \%$ \\
\hline $\mathrm{Cr}$ & wt\% & $6.61 \mathrm{E}-02$ & $3.83 \mathrm{E}-02$ & $42 \%$ \\
\hline $\mathrm{Hg}$ & wt $\%$ & $1.01 \mathrm{E}-03$ & $3.65 \mathrm{E}-05$ & $96 \%$ \\
\hline $\mathrm{K}$ & wt $\%$ & $1.05 E+00$ & $1.24 \mathrm{E}+00$ & $18 \%$ \\
\hline Mn & wt $\%$ & $1.82 \mathrm{E}-02$ & $2.96 \mathrm{E}-04$ & $98 \%$ \\
\hline $\mathrm{Na}$ & $\mathrm{wt} \%$ & $2.93 \mathrm{E}+01$ & $3.16 \mathrm{E}+01$ & $8 \%$ \\
\hline $\mathrm{Si}$ & $\mathrm{wt} \%$ & $1.44 \mathrm{E}-01$ & $4.83 \mathrm{E}-02$ & $67 \%$ \\
\hline $\mathrm{Zn}$ & $w t \%$ & $7.55 \mathrm{E}-03$ & $9.91 \mathrm{E}-04$ & $87 \%$ \\
\hline \multicolumn{5}{|l|}{ ICP-MS } \\
\hline $\mathrm{U}^{235}$ & wt $\%$ & 4.19E-05 & $2.08 \mathrm{E}-05$ & $50 \%$ \\
\hline$U^{238}$ & $w t \%$ & $5.52 \mathrm{E}-03$ & $2.90 \mathrm{E}-03$ & $48 \%$ \\
\hline $\mathrm{Tc}^{99}$ & wt $\%$ & $1.68 \mathrm{E}-03$ & $8.25 \mathrm{E}-04$ & $51 \%$ \\
\hline
\end{tabular}


Table 13. Composition of the Calculated Composite and Diluted Composite from Data Contained in the Tank Characterization Report ${ }^{6}$ Compared with the Filtered Supernatant of the First Half of the 241-AN-103 Sample Received at SRTC Diluted to $\sim 5$ M Sodium.

\begin{tabular}{|c|c|c|c|c|c|}
\hline & Units & $\begin{array}{l}\text { Calculated } \\
\text { Composite }\end{array}$ & $\begin{array}{c}\text { Calculated } \\
\text { Diluted } \\
\text { Composite }\end{array}$ & $\begin{array}{c}\text { Filtered } \\
\text { Supernatant } \\
\text { (from Table 6) }\end{array}$ & $\begin{array}{c}\text { Percent } \\
\text { Difference }\end{array}$ \\
\hline $\mathrm{Na}$ & $\mathbf{M}$ & $1.39 \mathrm{E}+01$ & $5.25 \mathrm{E}+00$ & $5.25 \mathrm{E}+00$ & $0 \%$ \\
\hline $\mathrm{Al}$ & $\mathbf{M}$ & $2.39 \mathrm{E}+00$ & $9.03 \mathrm{E}-01$ & $6.98 \mathrm{E}-01$ & $29 \%$ \\
\hline $\mathrm{Cr}$ & $M$ & $1.40 \mathrm{E}-02$ & $5.29 \mathrm{E}-03$ & $1.41 \mathrm{E}-03$ & $275 \%$ \\
\hline K & $\mathbf{M}$ & $3.60 \mathrm{E}-01$ & $1.36 \mathrm{E}-01$ & $1.21 \mathrm{E}-01$ & $12 \%$ \\
\hline $\mathrm{Si}$ & $\mathbf{M}$ & $1.60 \mathrm{E}-02$ & $6.04 \mathrm{E}-03$ & 4.48E-03 & $35 \%$ \\
\hline$\left[\mathrm{NO}_{3}{ }^{-}\right]$ & M & $2.53 \mathrm{E}+00$ & $9.56 \mathrm{E}-01$ & $1.57 \mathrm{E}+00$ & $39 \%$ \\
\hline$\left[\mathrm{NO}_{2}^{-}\right]$ & $\mathbf{M}$ & $2.24 \mathrm{E}+00$ & $8.46 \mathrm{E}-01$ & $1.04 \mathrm{E}+00$ & $19 \%$ \\
\hline$\left[\mathrm{Cl}^{-}\right]$ & $\mathbf{M}$ & $2.30 \mathrm{E}-01$ & 8.69E-02 & $6.15 \mathrm{E}-02$ & $41 \%$ \\
\hline$[\mathrm{F}]$ & $\mathbf{M}$ & $5.80 \mathrm{E}-02$ & 2.19E-02 & $8.49 \mathrm{E}-03$ & $158 \%$ \\
\hline
\end{tabular}


Table 14. Composition of the Calculated Diluted Liquid Composite from Data Contained in the Tank Characterization Report ${ }^{6}$ Compared with the Filtered Supernatant of the First Half of the 241-AN-103 Sample Received at SRTC Diluted to $\sim 5$ M Sodium.

\begin{tabular}{|c|c|c|c|c|}
\hline & Units & $\begin{array}{c}\text { Calculated } \\
\text { Diluted Liquid } \\
\text { Composite }^{6} \\
\end{array}$ & \begin{tabular}{|c|} 
Filtered \\
Supernatant (from \\
Table 6, 7) \\
\end{tabular} & $\begin{array}{c}\text { Percent } \\
\text { Difference }\end{array}$ \\
\hline $\mathrm{Cs}^{137}$ & $\mu \mathrm{Ci} / \mathrm{ml}$ & $3.53 \mathrm{E}+02$ & $1.94 \mathrm{E}+02$ & $82 \%$ \\
\hline $\mathrm{Tc}^{99}$ & $\mu \mathrm{Ci} / \mathrm{ml}$ & $7.98 \mathrm{E}-05$ & $3.30 \mathrm{E}-02$ & $100 \%$ \\
\hline $\mathrm{Sr}^{90}$ & $\mu \mathrm{Ci} / \mathrm{ml}$ & $9.95 \mathrm{E}-03$ & $1.99 \mathrm{E}-02$ & $50 \%$ \\
\hline$\left[\mathrm{NO}_{3}{ }^{-}\right]$ & $\mathrm{M}$ & $8.99 \mathrm{E}-01$ & $1.57 \mathrm{E}+00$ & $43 \%$ \\
\hline$\left[\mathrm{NO}_{2}^{-}\right]$ & $\mathrm{M}$ & $1.38 \mathrm{E}+00$ & $1.04 \mathrm{E}+00$ & $32 \%$ \\
\hline$\left[\mathrm{C}_{2} \mathrm{O}_{4}{ }^{2-}\right]$ & M & $1.56 \mathrm{E}-02$ & $5.88 \mathrm{E}-03$ & $165 \%$ \\
\hline$\left[\mathrm{Cl}^{-}\right]$ & $\mathrm{M}$ & $1.33 \mathrm{E}-01$ & $6.15 \mathrm{E}-02$ & $117 \%$ \\
\hline$[\mathrm{F}]$ & $\mathbf{M}$ & $1.50 \mathrm{E}-02$ & $8.49 \mathrm{E}-03$ & $77 \%$ \\
\hline$\left[\mathrm{CH}_{2} \mathrm{O}^{-}\right]$ & M & 1.73E-02 & 2.63E-02 & $34 \%$ \\
\hline$\left[\mathrm{OH}^{-}\right]_{\text {free }}$ & $\mathbf{M}$ & $2.76 \mathrm{E}+00$ & $2.17 \mathrm{E}+00$ & $27 \%$ \\
\hline Al & $\mathbf{M}$ & $5.69 \mathrm{E}-01$ & $6.98 \mathrm{E}-01$ & $18 \%$ \\
\hline $\mathrm{Cr}$ & $\mathbf{M}$ & $5.16 \mathrm{E}-03$ & $1.41 \mathrm{E}-03$ & $266 \%$ \\
\hline $\mathrm{K}$ & $M$ & $2.11 \mathrm{E}-01$ & $1.21 \mathrm{E}-01$ & $75 \%$ \\
\hline $\mathrm{Li}$ & $\mathbf{M}$ & $1.05 \mathrm{E}-03$ & $2.18 \mathrm{E}-04$ & $380 \%$ \\
\hline Mo & $\mathbf{M}$ & $5.40 \mathrm{E}-04$ & $3.56 \mathrm{E}-04$ & $52 \%$ \\
\hline $\mathrm{Na}$ & $\mathbf{M}$ & $5.25 \mathrm{E}+00$ & $5.25 \mathrm{E}+00$ & $0 \%$ \\
\hline $\mathrm{P}$ & M & $4.23 \mathrm{E}-03$ & $9.71 \mathrm{E}-03$ & $56 \%$ \\
\hline $\mathrm{Si}$ & M & $3.24 \mathrm{E}-03$ & $4.48 \mathrm{E}-03$ & $28 \%$ \\
\hline TIC & $\mathrm{mg} / \mathrm{L}$ & $5.18 \mathrm{E}+02$ & $2.52 \mathrm{E}+03$ & $79 \%$ \\
\hline TOC & $\mathrm{mg} / \mathrm{L}$ & $1.37 \mathrm{E}+03$ & $3.76 \mathrm{E}+02$ & $263 \%$ \\
\hline Total U & $\mathrm{mg} / \mathrm{L}$ & $3.46 \mathrm{E}-06$ & $1.90 \mathrm{E}-06$ & $82 \%$ \\
\hline
\end{tabular}


Table 15. Composition of the Solids Composite from Data Contained in the Tank Characterization Report ${ }^{6}$ Compared with the Total Dried Solids of the First Half of the 241-AN-103 Sample Received at SRTC Diluted to $\sim 5$ M Sodium.

\begin{tabular}{|l|c|c|c|c|}
\hline & Units & Solids Composite $^{6}$ & $\begin{array}{c}\text { Total Dried Solids } \\
\text { (from Tables 8, 9) }\end{array}$ & $\begin{array}{c}\text { Percent } \\
\text { Difference }\end{array}$ \\
\hline $\mathrm{Cs}^{137}$ & $\mu \mathrm{Ci} / \mathrm{g}$ & $2.74 \mathrm{E}+02$ & $5.12 \mathrm{E}+02$ & $46 \%$ \\
$\mathrm{Tc}^{99}$ & $\mu \mathrm{Ci} / \mathrm{g}$ & $1.44 \mathrm{E}-01$ & $2.86 \mathrm{E}-01$ & $50 \%$ \\
$\mathrm{Sr}^{90}$ & $\mu \mathrm{Ci} / \mathrm{g}$ & $2.66 \mathrm{E}+00$ & $4.79 \mathrm{E}+00$ & $44 \%$ \\
$\mathrm{Al}$ & $w t \%$ & $3.82 \mathrm{E}+00$ & $5.94 \mathrm{E}+00$ & $36 \%$ \\
$\mathrm{Cr}$ & $w \mathrm{wt} \%$ & $4.38 \mathrm{E}-02$ & $6.61 \mathrm{E}-02$ & $34 \%$ \\
$\mathrm{Fe}$ & $w t \%$ & $4.85 \mathrm{E}-03$ & $7.47 \mathrm{E}-02$ & $94 \%$ \\
$\mathrm{~K}$ & $w \mathrm{wt} \%$ & $6.54 \mathrm{E}-01$ & $1.05 \mathrm{E}+00$ & $38 \%$ \\
$\mathrm{Mo}$ & $w t \%$ & $4.27 \mathrm{E}-03$ & $9.85 \mathrm{E}-03$ & $57 \%$ \\
$\mathrm{Na}$ & $w t \%$ & $2.17 \mathrm{E}+01$ & $2.93 \mathrm{E}+01$ & $26 \%$ \\
$\mathrm{P}$ & $w t \%$ & $1.15 \mathrm{E}-01$ & $7.40 \mathrm{E}-02$ & $55 \%$ \\
$\mathrm{Si}$ & $w t \%$ & $8.38 \mathrm{E}-02$ & $1.44 \mathrm{E}-01$ & $42 \%$ \\
$\mathrm{Zn}$ & $w t \%$ & $7.12 \mathrm{E}-04$ & $7.55 \mathrm{E}-03$ & $91 \%$ \\
\hline
\end{tabular}

